\title{
Sentence openers in academic writing: A comparison between seminar texts and students' reflective writing papers
}

\author{
Tanju Deveci*
}

\section{APA Citation:}

Khalifa University of Science and Technology, Abu Dhabi, 2533, the United Arab Emirates

Deveci, T. (2019). Sentence openers in academic writing: A comparison between seminar texts and students' reflective writing papers Journal of Language and Linguistic Studies, 15(1),247-261.

Submission Date:23/01/2018

Acceptance Date: $11 / 08 / 2018$

\begin{abstract}
Language used to report research findings and put forward arguments is at the heart of effective communication with readers. To this end, scholars use a variety of stylistic features. One of these is variety in language, which includes structures, lexis, and organization markers. Although much research has been conducted on these aspects, a particular feature has received limited interest from researchers: sentence openers, a strategic use of which helps authors develop an individual style, and avoid stagnant prose. This helps them maintain readers' interest while communicating scientific knowledge. Due to the importance of sentence openers in scientific prose, university students' awareness should be raised about this aspect of academic writing. This requires identification of commonly occurring sentence openers in the texts they study. It is also useful to identify student tendencies regarding sentence openers and their perceived competence in varying sentence openers. Prompted by these necessities, this research investigated a 10,949 running-word corpus compiled from professionally-written texts used in a first-year writing course, as well as a 42,070 running-word student corpus compiled from the reflective writing papers of 35 first-year students. Data on students' perceived competence were collected using a survey. Results showed that the two most frequent sentence openers in both corpora were subject-verb and transition markers. However, the latter were used by the students with significantly higher frequency than they were by the professional writers. Data also revealed that the students lack awareness of sentence openers as a feature for making writing more interesting. Students further reported an inability to use a wide range of sentence openers in their writing. Results are discussed, and recommendations are made for increasing students' skill in composing effective academic texts.
\end{abstract}

(C) 2019 JLLS and the Authors - Published by JLLS.

Keywords: Sentence openers; sentence variety; academic writing; voice

\section{Introduction}

It is axiomatic among seasoned authors, as well as among those teaching rhetoric and composition to college students, that the way in which ideas are expressed has a significant impact on readers' understanding and reactions. Although authors are bound to have their own ways of writing in which they establish a distinct voice for themselves, they often follow some basic conventions in the genre they write. As a distinctive genre, academic writing, too, has certain commonly accepted conventions. Indisputably, scholars' wealth of scientific knowledge, particularly generated through research, is of

\footnotetext{
* Corresponding author. Tel.: +97126075531

E-mail address: tanju.deveci@ku.ac.ae
} 
utmost importance. This knowledge should be shared with wider audiences. However, unless expressed 'adequately,' research results together with their argumentation receive limited dissemination. Considering the fact that the first communication between an author and readers is usually the text itself, "the first impression of the reader is inevitably influenced by the way the message is communicated" (Deveci \& Nunn, 2018, p. 17). Therefore, language is second only to content, if not first, as a factor determining the extent to which the message reaches readers successfully. Sharing this sentiment, Gopen and Swan (1990, p. 550) note that

[t]he fundamental purpose of scientific discourse is not the mere presentation of information and thought, but rather its actual communication. It does not matter how pleased an author might be to have converted all the right data into sentences and paragraphs; it matters only whether a large majority of the reading audience accurately perceives what the author had in mind.

It can justifiably be argued that authors have the responsibility to assist their readers in "accurately perceiving what they have in mind" (Gopen \& Swan, 1990). As emphasized above, efficient use of language is a factor determining how successful communication has been. As well as easing readers' understanding, it also helps authors develop their own unique styles. According to Walter (2017), using a mixture of simple, compound, and complex sentences helps authors vary sentence lengths, thus creating a rhythm that feels natural for them. Although much has been written about sentence variety (e.g. Struc \& Wood, 2011; Hashimoto, 1993; Wolfe, 1950) and some about sentence lengths (Deveci, in press) in written academic discourse, there is a scarcity of research devoted to how variety is achieved via sentence openers. Following hints in the literature that a certain type of sentence opener is "a staple of scientific writing" (Alley, 1996, p. 130), and "the way [authors] vary sentence openers helps determine [their] individual style[s]" and "failure to vary sentence openers will stagnate [their] prose and exhaust [their] readers" (Alley, 1996, p. 133), this research focuses on sentence openers in academic writing by competent authors as well as university students pursuing education in English as a foreign language in their local context. It also appears that students' perceived competence in composing academic texts in a foreign language has not been investigated with a view towards sentence openers. Students require a minimum proficiency score in English to be eligible for their studies at Englishmedium universities. Having achieved this, they may not be so concerned about ways to make their writing interesting for their target audience. They may not be fully aware of the variety of sentence openers at their disposal. They may also lack the confidence to vary their language use by employing different sentence openers.

Much insight can be gained from this investigation. First, identification of commonly occurring sentence openers in texts written by competent authors could give novice authors, whether 'native' or 'non-native,' insight into different ways of establishing rhythm and voice in their own writing. Second, identification of how training students perceive their competence in using a variety of sentence openers and meld their texts together could help identify student strengths as well as areas in which they need improvement. This will help rhetoric and composition instructors devise instructional interventions to support learner development. The latter in particular was prompted by my own experience teaching firstyear students in a writing-intensive course. Together, these reasons gave this research the impetus to identify different types of sentence openers used in texts written by both capable writers and students of English as foreign language, as well as the desire to expand students' awareness of strategies that can be used to make their writing more interesting to read. 


\subsection{Literature review}

\subsubsection{Sentence variety and sentence openers}

Authors' tactical choices of different types of sentences help them use variety in their prose, making their texts more interesting to read. According to Walter (2017), variety can be achieved by using a mixture of sentence types such as simple, compound, and complex. Consequently, writing becomes more sophisticated (Mamishev \& Williams, 2010). This also helps vary sentence length. The American Psychological Association (2009) notes that "[v]aried sentence length helps readers maintain interest and comprehension" (p. 68). A mixture of short and long sentences also helps authors avoid stagnation and establish a rhythm in their writing (Alley, 1996), further helping readers maintain interest.

In addition to varied sentence length, a variety of language structures can be used to make writing more sophisticated. Some of these include the active and passive voices, adjectival clauses, noun clauses, inverted sentences, participles, cleft sentences, synonyms, and prepositional phrases. An explanation of each of these is beyond the scope of this study. However, the use of these structures, often employed in combination in scientific discourse, impacts sentence length as well as sentence types. To illustrate, the use of multiple prepositional phrases (underlined), adjectival clauses (in bold), and a noun clause (in italics) in the excerpt below ${ }^{\dagger}$ increases the sentence length significantly.

In the field of financial literacy, which also displays a gender bias favouring men in terms of scores on financial literacy tests, Agnew and Cameron-Agnew (2015) found that financial conversations in the home between parents and children occurred at an earlier age with

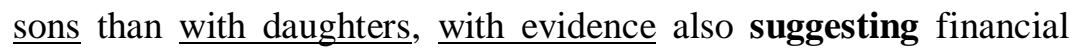
discussions with daughters were at a more superficial level.

Defined as "any structure or combination of structures that occupies the introductory position of a sentence" (Killgallon, 1987, p. 91), a sentence opener helps authors achieve sophistication in their writing and maintain readers' interest while facilitating their comprehension. Alley (1996, p. 130) identifies seven main types of sentence openers, as shown in the following table.

Table 1. Seven types of sentence openers

\begin{tabular}{ll}
\hline \multicolumn{1}{c}{ Sentence Openers } & \multicolumn{1}{c}{ Examples } \\
\hline $\begin{array}{l}\text { Subject-verb } \\
\text { Prepositional words }\end{array}$ & $\begin{array}{l}\text { Mount St. Helens erupted on May, 1980. } \\
\text { Within minutes, the cloud devastated more than } 500 \text { square kilometers of forests and } \\
\text { lakes. } \\
\text { Recently, debate has arisen over the source for the steam. } \\
\text { Transition words } \\
\text { Introductory clause }\end{array}$ \\
$\begin{array}{l}\text { Although the effects of the eruption were well documented, the origin is not well } \\
\text { understood. }\end{array}$ \\
$\begin{array}{l}\text { To understand the source of steam in volcanic eruptions, we have to determine how } \\
\text { much water the magma contains. }\end{array}$ \\
$\begin{array}{l}\text { Participial phrase } \\
\text { Verb }\end{array}$ & \begin{tabular}{l} 
Is it groundwater heated by magma or water originally dissolved in the magma itself? \\
\hline Adapted
\end{tabular}
\end{tabular}

Adapted from Alley (1996, p.130)

\footnotetext{
${ }^{\dagger}$ Excerpt taken from Agnew and Harrison (2017), which was a part of corpus used in research by Deveci \& Nunn (2018).
} 
A variety of factors play a role in authors' decisions to choose a particular sentence opener over others. According to Alley (1996), the majority of sentences in scientific writing have subject-verb openers; since such sentences are "the most direct way to state details, [therefore] they are valuable for opening sentences to sections and subsections and for stating important results" (p. 133). On the one hand, Smith (1982) states that "the type of sentence opener is ... an indication of transition between sentences" (p. 192). On the other hand, Imam (2013) notes certain types of sentence openers can be effective in texts composed to persuade readers. For instance, a verb starter in a question (e.g. "Wouldn't you agree that...?") may increase the chances of the reader saying, "Yes." Furthermore, a verb starter in the imperative form can be used to introduce an example (e.g. "Take bullying as an example. A victim of bullying would be subjected to negative interpersonal communication with other." ) Other reasons for using the imperative in academic written discourse include engaging the reader, achieving text economy, and establishing a personal writing style (Swales, et. al., 1998). Additionally, some sentence openers can be employed for emphasis purposes. Noun clauses embedded question words as openers are examples of this, as in "What I didn't realize at the time was how my classmate...."

Pennington (2009) points out that "good" sentence variety can be established through the use of 50\% subject-verb sentence openers and 50\% other types of openers. However, Alley (1996) warns that a set pattern in which these should be used does not exist; yet, it is important that authors vary their use of sentence openers so that they refrain from stagnant prose. In this way, authors can avoid exhausting their readers. Empirical evidence indicates a negative correlation between the quality of a text and the unvaried frequency of the syntactical pattern of a subject opening (Myhill, 2008).

Although little recent research seems to have been conducted into university students' use of sentence openers in their prose, past research conducted on first-year composition students' use of variety in expository writing by Riley (1964) showed that the adverbial opener was the most common, while verbal and inverted forms were the least frequent. The comparison between student papers and papers by professional writers revealed that the latter used the inverted opener rather sparingly. It should, however, be noted that the students in Riley's study were native-speakers of English.

\subsection{Research context, rationale for the study, and research questions}

This research was undertaken in the context of Khalifa University of Science and Technology (KUST) which offers engineering degrees. The English Department at the university teaches first-year students rhetoric and composition skills along with communication skills essential for their academic studies and future professional lives. To this end, the second course (ENGL112), which is based on the principles of Project-Based Learning (PBL), requires students to carry out a term-long research project on a variety of topics including communication theories. To supplement students' knowledge in this area, seminars are held on effective listening, interpersonal communication, intrapersonal communication, and intercultural communication. For each, students are assigned academic texts. Seminars are followed by reflective writing examinations.

Writing is an integral part of the course; however, students improve their writing skills through experiential learning. Motivated by an orientation towards incidental learning prompted by students' experiential learning experiences, instructors may not generally utilize explicit form-focused instruction. My own observations together with anecdotal evidence from other instructors indicate that students' comprehension of assigned texts are generally adequate. However, a common complaint from faculty is that students' reflective writing lacks originality in its use of language. This is often reflected in lower grades for the language component compared to the other three components (i.e. task, content, and

\footnotetext{
${ }^{\ddagger}$ Example is from student corpus of this study.

$\S$ Example is from student corpus of this study.
} 
organization). Although problems with grammar, punctuation, and spelling mistakes also factor into the lower grades, the lack of the desired level of sophistication in language use causes instructors to be critical of students' writing skills. I feel the students may not always be clear about what is meant with "sophisticated use of language." It may indeed include numerous (academic) stylistic features, one of which is sentence openers. I suspect students' attention is not drawn to this particular discourse feature in their previous language classes. Nor does it seem that it is an explicit item on instructors' teaching agendas. Collectively, these factors likely limit students' awareness of the variety of stylistic features available to them. This probably leads students to focus more on other elements of the rubric used to assess their writing at the expense of language use. Such orientation, conscious or subconscious, may also be caused by students' tendency to take language skills for granted. That is, having earned at least a minimum score from an English language proficiency examination to be eligible for their university studies, students may neglect efficient use of language. Added to this is instructors' potential expectation that students' exposure to a variety of linguistic features will result in incidental learning. However, the authors of the seminar texts used in ENGL112 may not necessarily have considered these when they were being drafted. Therefore, it would be useful to identify the commonly occurring types of sentence openers in these texts. It is also important to identify how students write academically in response to questions related to the seminar topics. Empirical evidence from students' own papers would help identify the types of sentence openers they tend to use in their writing. It also seems crucial to ascertain students' perceived competence in varying sentence openers to make their writing interesting for their readers. It is possible that a lack of confidence (or overconfidence) may be a factor determining how they write. Findings relative to these will help instructors plan and execute instructional interventions compatible with student needs. They will also help raise students' awareness about different ways of establishing their voice in their writing.

Given the importance of sentence openers in academic writing discussed above, this research seeks answers to the following questions:

1. How do the commonly occurring sentence openers used by the authors of the four seminar texts assigned in ENGL112 at KUST compare to those by EGNL112 students in their reflective writing examination papers?

2. How competent do students perceive themselves in using variety of sentence openers?

\section{Method}

\subsection{Corpora and analyses}

The first research question was answered through corpus analysis. To this end, two corpora were used. The first one was comprised of the four seminar texts on communication topics covered in the course: Effective Listening (3,236 words), Interpersonal Communication (2,425 words), Intrapersonal Communication (2,482 words), and Intercultural Communication (2,806 words). Collectively, these texts provided a corpus of 10,949 running words. These texts, with the exception of the first one, were drafted by the faculty in the department. The first one, on the other hand, was adapted from an openaccess source, (See Appendix A for a list of all four texts). In establishing this corpus, any tables, captions, and reference lists were not considered since they were outside of the scope of this study.

The second corpus was comprised of the three reflective writing examination papers students $(n=35)$ were required to write after the seminars. The first examination was on effective listening. The total number of words in the student examination papers on this topic was 10,587. The second examination covered both interpersonal and intrapersonal communication (with a total of 15,383 running words), while the last one covered intercultural communication and one other topic which the students were free 
to choose (at the end of the course, with a total of 16,100 running words). Collectively, these examination papers provided a corpus of 42,070 running words.

To prevent skewed responses, students were not informed about the aims of the research. However, they were provided with the rubrics used to assess their papers. One component of the rubric was the use of language, which included the following elements: style, expression, tone, range and accuracy of grammar and vocabulary, coordination between sentences and paragraphs, spelling, and punctuation. It is also important to note that students' engagement in writing examinations is expected to have created positive washback, thus enhancing their repertoire of sentence types and sentence beginners throughout the course.

In this study, Alley's (1996) classification of sentence openers was used for analysis purposes. Two researchers were involved at this stage. Upon a calibration meeting, the analyses were conducted separately. Later, the analyses were compared. Overall, there was $85 \%$ inter-rater reliability. The discrepancies were discussed, and consensus was reached. The accuracy of sentence openers and their structures was not included within the scope of this study.

\subsection{Survey and analysis}

Data for the second research question were collected using a self-reporting survey, adapted from Pennington (2009). This survey included statements relative to different types of sentence types identified by Alley (1996). Sample statements included "In my writing, I start sentences with preposition phrases," "In my writing, I start sentences with introductory clauses," and "In my writing, I vary the subject-verb-object pattern." To ensure student understanding, two examples were given for each statement. The students were asked to indicate how often they used what were identified as sentence openers in the statements.

Scores students could receive ranged between 9 and 45. A score lower than 24 indicates that the student was not able to write with sentence variety because he did not know his grammar well enough. A score between 24 and 29 indicates that the student was not able to write with much sentence variety because he did not know her grammar well enough. A score between 30 and 34 indicates that the student planned his writing with sentence variety as a focus, but he did not know his grammar well to improve his writing style. On the other hand, a score between 35 and 40 indicates that the student planned his writing with sentence variety as a focus, and he knows knew some grammar to help him improve his writing style. Finally, a score higher than 41 indicates that the student planned his writing with sentence variety as a focus and knew his grammar well enough to improve his writing style.

\section{Results}

The first research question asked how the commonly occurring sentence openers used by the authors of the four seminar texts assigned in ENGL112 compare to those by students in their reflective writing examination papers. To this end, first the commonly occurring sentence openers in the seminar texts were identified. The results are summarized in Table 2 below. 
Table 2. Sentence openers in seminar texts

\begin{tabular}{ccccccccccc}
\hline \multirow{2}{*}{ Sentence Openers } & \multicolumn{1}{c}{ Effective } & \multicolumn{2}{c}{ Interpersonal } & \multicolumn{2}{c}{ Intrapersonal } & \multicolumn{2}{c}{ Intercultural } & \multicolumn{2}{c}{ Total } \\
& Listening & \multicolumn{2}{c}{ Communication } & \multicolumn{2}{c}{ Communication } & Communication & & \\
& $\mathrm{f}$ & $\%$ & $\mathrm{f}$ & $\%$ & $\mathrm{f}$ & $\%$ & $\mathrm{f}$ & $\%$ & $\mathrm{f}$ & $\%$ \\
\hline Subject-verb & 108 & 67 & 77 & 71 & 83 & 69 & 73 & 62 & 341 & 67.26 \\
Prepositional phrase & 7 & 4 & 4 & 4 & 6 & 5 & 5 & 4 & 22 & 4.34 \\
Transition words & 17 & 11 & 24 & 22 & 27 & 22 & 27 & 23 & 95 & 18.74 \\
Introductory clause & 16 & 10 & 2 & 2 & 3 & 2 & 8 & 7 & 29 & 5.7 \\
Infinitive phrase & 8 & 5 & 0 & 0 & 2 & 2 & 0 & 0 & 10 & 2 \\
Participle phrase & 0 & 0 & 0 & 0 & 0 & 0 & 2 & 2 & 2 & 0.4 \\
Verb (question) & 5 & 3 & 0 & 0 & 0 & 0 & 2 & 2 & 7 & 1.4 \\
Verb (Imperative) & 0 & 0 & 1 & 1 & 0 & 0 & 0 & 0 & 1 & 0.2 \\
Total & 161 & 100 & 108 & 100 & 121 & 100 & 117 & 100 & 507 & 100 \\
\hline
\end{tabular}

Table 2 shows that the most commonly used sentence opener was subject-verb with a frequency of $341(67.26 \%)$ of the 507 sentences in the entire corpus. This was the case with the four sub-corpora, too. Subject-verb type sentence openers were followed in frequency by transition words (18.74\%), introductory clauses (5.7\%), and prepositional phrases (4.34\%). Less frequently used openers included infinitive phrases $(2 \%)$, questions $(1.4 \%)$, participle clauses $(0.4 \%)$, and imperatives $(0.2 \%)$. Collectively, these data clearly show that the corpus mainly contained sentence openers embedding subject-verb structures and transition words.

When the individual seminar texts are considered, it is seen that the subject-verb pattern was again the most common type in all four texts. Similarly, transition words were the second most common in the texts. However, they were less frequent in the first seminar text $(11 \%)$ compared to the other three texts. On the other hand, introductory clauses as sentence openers were used more frequently in the Effective Listening (10\%) and the Intercultural Communication (7\%) texts than in the other two texts. No infinitive phrases were detected in the second and fourth texts, to go with just $5 \%$ and $2 \%$ in the first and third texts, respectively. On the other hand, there were only two instances of participle phrases in the last seminar text, with none in the others. Questions were employed only in the first and the last texts (5\% and 2\%, respectively). Finally, there was a single instance of an imperative in the second text.

To answer the first research question, the students' use of different types of sentence openers in their reflective writing examination papers was also investigated. A summary of the results is given in Table 3.

Table 3. Sentence openers in student corpus

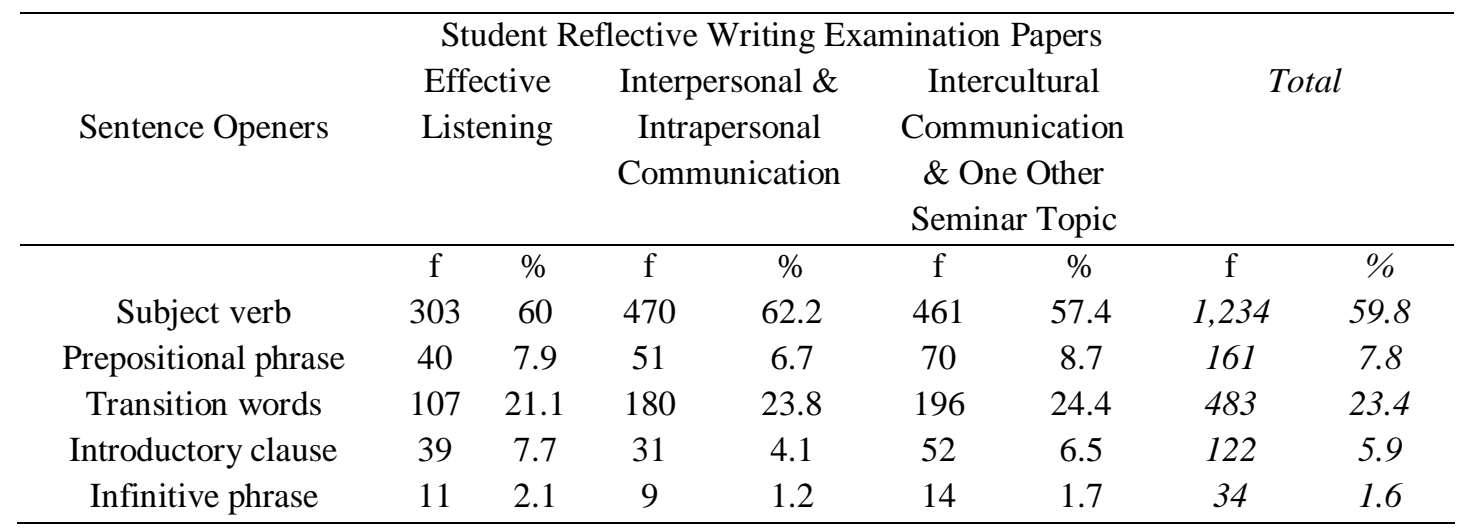




\begin{tabular}{ccccccccc}
\hline Participle phrase & 4 & 0.8 & 6 & 0.8 & 4 & 0.5 & 14 & 0.7 \\
Verb (question) & 1 & 0.2 & 3 & 0.4 & 3 & 0.4 & 7 & 0.3 \\
Imperative & 1 & 0.2 & 6 & 0.8 & 3 & 0.4 & 10 & 0.5 \\
Total & 506 & 100 & 756 & 100 & 803 & 100 & 2,065 & 100 \\
\hline
\end{tabular}

Table 3 shows that the most common sentence opener in the student corpus was subject-verb, which was used 1,234 times (59.8\%). This was followed by transition words with a frequency of 483 (23.4\%). Although comparatively much less frequent than the first two, a prepositional phrase was the third most common sentence opener, being used 161 times (7.8\%). This was followed by introductory clauses $(5.9 \%)$, infinitive phrases $(1.6 \%)$, participle phrases $(0.7 \%)$, imperatives $(0.5 \%)$, and questions $(0.3 \%)$. The t-test run to compare the frequencies of sentence openers in the seminar texts corpus and student corpus revealed a lack of statistically significant difference $(t=0.0004, p=0.4998)$. However, it is important to note that the last reflective writing examination papers included comparatively fewer subject-verb openers, but more prepositional phrases and transition words.

The second research question aimed to identify the students' perceived competence in varying sentence openers. The results are summarized in Table 4.

Table 4. Students' perceived competence in varying sentence openers

\begin{tabular}{lcccc}
\hline \multicolumn{1}{c}{ Statements } & Min & Max & $\overline{\mathrm{x}}$ & $\mathrm{SD}$ \\
\hline In my writing, I vary the subject-verb-object pattern. & 3 & 5 & 3.9 & 0.73 \\
I start sentences with preposition phrases. & 1 & 5 & 3.4 & 0.98 \\
I start sentences with transition words. & 3 & 5 & 4.4 & 0.71 \\
I start sentences with introductory clauses. & 2 & 5 & 4.1 & 0.81 \\
I start sentences with infinitive phrases. & 1 & 5 & 3.8 & 1.08 \\
I start sentences with participle phrases (adjective). & 1 & 4 & 2.3 & 0.77 \\
I start sentences participle phrases (__ or_en verbs). & 1 & 5 & 3.7 & 1.05 \\
I start sentences participle phrases (__ing verbs). & 1 & 5 & 3.1 & 1.12 \\
I start sentences with verbs. & 1 & 5 & 3.4 & 0.92 \\
Total & 21 & 38 & 32 & 4.5 \\
\hline
\end{tabular}

Table 4 shows that the students' scores for the survey ranged between 21 and $38(\mathrm{SD}=4.5)$, with an overall average of 32. This indicates that the students had a tendency to plan their writing with sentence variety as a focus, but they did not know their grammar well enough to improve their writing styles. The average score for the first statement relative to students' general tendency to vary the subject-verb-object pattern was 3.9 out of 5 , indicating a relatively strong perceived skill. They indicated particular readiness for using transition words and introductory clauses as sentence openers ( $\bar{x}=4.4$ and 4.1 , respectively). However, they were found to lack skill in using participle clauses. They rated themselves weak in using participle clauses, embedding adjectives in particular $(\overline{\mathrm{x}}=2.3, \mathrm{SD}=0.77)$. In fact, twenty-one of the students gave themselves a rating of below 3 for this item. This was followed by participle phrases embedding a gerund $(\overline{\mathrm{x}}=3.1, \mathrm{SD}=1.12)$. Eleven students gave themselves a rating of below 3 for this statement. On the other hand, their self-rating for participle clauses embedding a past participle was comparatively higher, but still five students rated themselves below $3(\mathrm{SD}=1.05)$.

\section{Discussion}

The first research question aimed to compare the sentence opener profile of the seminar texts to that of the reflective writing examination papers produced by the students. For this purpose, first a 10,949 running-word corpus comprised of four seminar texts was analyzed. The results showed that the most 
commonly used sentence opener in the seminar texts was subject-verb (67.26\%). This is somewhat above Pennington's (2009) recommendation of a 50\% subject-verb sentence opener in academic writing. However, in deciding whether or not this is desirable, one needs to consider Alley's (1996) warning about refraining from a set pattern so long as authors pay attention to varying their openers to avoid stagnant prose. Considering the range in other types of openers used in the four seminar texts, it could justifiably be argued that the texts contain a somewhat wide range without exhausting readers. However, it is also important to note the frequency of transition words $(18.74 \%)$ in the seminar texts. It is a fact that an author's ineffective choice of language structures, lexis and terminology in an academic text may place a strain on readers. To reduce this problem, authors are advised to signal when they are moving from one idea or topic to another, which is often done by using transition words (e.g. "however" and "nevertheless") to guide readers down the paths of arguments (Starkey, 2015). This is likely why transition words were the second most common sentence-opener in the corpora in this study.

On the other hand, introductory sentences as sentence openers together with prepositional phrases were used with markedly lower frequencies ( $5.7 \%$ and $4.34 \%$, respectively). The former help construct complex sentences, which are quite frequent in academic prose. Authors are often advised to consider the sentence that precedes a complex sentence when they need to make a decision about whether they should start a complex sentence with an independent or a dependent clause (i.e. an introductory sentence in this case) (Raimes \& Miller-Cochran, 2018). The decision is often influenced by the author's attempt to "avoid repetition or following through with a subject or topic chain" (p. 450). It is likely that the authors of the four seminar texts may have been prompted by similar motivations subconsciously. Regarding the latter, Hinkel (2004) noted that that prepositional phrases are commonly used in academic writing partly because they provide a compact structure for information. However, Hinkel also points out that their position in the sentence can differ. The results of this study provide some evidence that prepositional phrases may be used as sentence openers rather sparingly in academic writing.

It is also important to consider the fact that the target audience of these texts are first-year students with a limited academic background. In fact, except for the first seminar text on effective listening, all the texts were written for students of English as a foreign language. It is likely that the authors made conscious decisions about the language they used in their texts. As one of the authors of the third seminar text (Intrapersonal Communication), I personally did consider students' linguistic background and the challenges they might face in comprehending the text, which resulted in producing a somewhat simplified/adapted version of a manuscript previously submitted for publication in an academic journal. Although we did not pay explicit attention to sentence openers in adapting the text, our choices may well have been affected by such factors. Kim and Snow (2009) report findings of previous research showing that elaboration (e.g. texts provided with paraphrases and synonyms) and simplification (e.g. through syntax) of texts help language learners' reading comprehension. Similarly, despite their limitations, simplified approaches to writing are argued to be effective for lower levels of students whose native language is not English (Jia, 2006). It is, therefore, suggested that teachers should adjust their teaching as students progress. This obviously applies to varying the ways in which students start sentences.

To answer the first research question, students' orientation towards sentence openers in their reflective writing examination papers on the seminar topics was investigated as well. The results revealed that the students, too, used subject-verb type most frequently (59.8\%). This is another indication that academic writing, be it produced by proficient speakers of English or by English language learners at a freshman level, contains mostly subject-verb openers (Pennington, 2009; Alley, 1996). This may be a promising result for students' language development in general, and scientific writing in particular. Also, transition words were the second most common type of sentence opener in both corpora. However, the student corpus included much more frequent use of transition words (23.4\% vs. 18.74\%). 
Although in this study I did not investigate the quality of transition markers (or any other types of sentence openers), it is important to highlight the fact that too frequent use of such markers likely makes writing obscure and reduces readability (Hogsette, 2009). The students' comparatively greater reliance on transition markers may have been caused by native language (L1) transfer. Previous research has showed that influenced by L1, native Arabic speakers tend to use a particular transition marker with higher frequency when composing academic texts in English (Sayidina, 2010). Although L1 interference was outside of the scope of this study in terms of the frequency of transition markers or writers' preference for certain markers over others, it is possible that the students' writing behaviors in L1 may have prompted them to use a greater number of transition markers (or a certain type of transition marker) in the reflective writing papers analyzed in this research.

The similarities between the two corpora (i.e. seminar texts \& student reflective writing papers) may in part have been caused by the students' tendency to take the seminar texts as a model. This may (not) have been a conscious decision on the part of the students. It is important to note that the writing examinations were open-book. It is possible that at least some of the students expressed themselves using the language structures in the seminar texts. Considering the fact that sentence openers are the first elements in sentences, the students' attention may have been drawn to them. This likely resulted in their tendency to use similar sentence openers. This may be partly caused by time pressure experienced during the examinations. A fifty-minute block was assigned for each reflective writing examination. Students in other open-book examinations have been found to devote extensive amount of time to locating the necessary information in the texts. Left with little time, they had difficulty in formulating and writing out their answers (Theophilides \& Koutselini, 2000). If the students in this study, too, behaved in this way without enough preparation prior to the examinations, they are likely to have rushed their writing with a subconscious decision to imitate language used in the seminar texts.

It is also argued that students' perception about the relative ease of open-book examinations causes less preparation (Ioannidou, 1997; Theophilides \& Koutselini, 2000). It is possible that the students in this study may have behaved similarly, leading them to rely more on the language used in the seminar texts during the examinations.

Another possible reason for the students' tendency to use subject-verb type more frequently (like the authors of the seminar texts) may be L1 transfer. It is possible that academic texts in Arabic incorporate this particular sentence opener more frequently than others. However, to my knowledge, no previous study investigated this aspect of academic writing in Arabic, an area which merits investigation.

The second research question was related to the students' perceived competence in using a variety of sentence openers to make their writing interesting. From my observations and experiences teaching a similar body of students over the last six years, I can say that students tend to be more concerned about content when they are writing a reflective piece. Certainly, content is at the heart of effective writing. However, for the message expressed through content to reach readers successfully, the form in which it is communicated is of vital importance; this means the author is responsible for expressing information and ideas in intelligible ways (Gopen \& Swan, 1990). Data from the self-reporting survey showed that students' perceived competence in using a variety of sentence openers was moderate with some tendency to plan their writing with sentence variety. However, results also revealed that they did not feel particularly skillful in using grammar to improve their writing. As was also evidenced by data from their reflective writing examination papers, the students felt more confident about using subject-verb-object openers, along with transition words. They rated themselves as "much less strong" in terms of using participle clauses. Individual differences in perceived competence is a significant factor determining foreign language learners`strategy use (Liu, 2013), attainment in general (Sultan, 2012) and writing abilities in particular (Pajares \& Johnson, 1994). Considering these together with the data from the current study, it is essential that students' awareness be raised in terms of choices available to them and 
increase their self-confidence in using these in their own writing. From my own observations and anecdotal evidence from other colleagues, our writing courses seem to place too much emphasis upon correct grammar, punctuation, lexis, and transitions between ideas using varied transition markers and phrases. The lack of interest in sentence openers may also translate into instructors' lack of interest in raising students' awareness about this significant element of academic writing.

\section{Conclusion and recommendations}

This research investigated a relatively understudied aspect of sentence variety in academic writing: sentence openers, a certain type of which is considered as "a staple of scientific writing" (Alley, 1996). It is important to note that authors' mindful use of sentence openers helps achieve fluency in writing and maintains readers' interest. The results showed a general trend among competent writers (the authors of the texts analyzed in this study) as well as first year students (whose reflective writing examination papers were analyzed in this study). Just as there were similarities between the two, there were some differences, too. For example, both groups used the subject-verb opener more commonly than the other types of openers. However, the students used transition markers markedly more frequently. Data from a self-reporting survey showed that the students were not fully aware of the role of sentence openers in achieving variety, rhythm and voice in their writing. It was also found that the students did not feel particularly competent in using certain types of sentence openers. One of the ways in which this awareness gap can be reduced and students' competence can be enhanced is to gear teaching toward language strategies. Ringler (2015) notes that not many teachers plan to use language strategies to teach content areas. She finds it important to scaffold the academic language that students are required to produce. Thus, teachers are advised to model the use of academic language for students. To this end, she suggests writing language objectives identifying language structures needed for a lesson. This is obviously relevant to content teachers as well as language teachers.

Aligned with this, Paraskevas (2006) suggests an approach which she calls "Grammar Apprenticeship" to increase students' awareness about different ways of increasing their papers' readability and originality. In this approach, students are guided to analyze grammatical structures in texts written by accomplished authors. By doing so, students realize the choices authors make at the sentence level, helping them to develop "a feel for the beauty of language, for its power and strength and grace" (p. 65). When engaged in stylistic analysis of such touchstone texts, student raise their awareness of stylistic effectiveness. When they are revising their own papers in light of this, they gain access to concrete, specific ways to write their own sentences, and improve the tone and voice of their writing. With this increased understanding of the role of sentence openers, they can make their own individual informed decisions about how to express factual information, their ideas, and feelings. This resonates with Krashen's (1984) view that competent writing skills are normally acquired as a result of engagement in extensive reading of texts composed by competent authors.

Another way to help students write using a variety of sentence openers is through paraphrasing exercises. Students can be asked to restate sentences using a particular set of sentence openers. This may be particularly useful with in-text citations. To exemplify, a direct quote may be paraphrased using a prepositional phrase (e.g. "In an experimental study, X found that ..."), an introductory clause (e.g. "When he experimented with this, X found that ..."), an infinitive phrase (e.g. "To test this, X did... and found that ...), or even an imperative (e.g. "Take the experimental study conducted by $\mathrm{X}$ as an example.") Another paraphrasing activity can be in the format of editing. For this purpose, students can be provided a short text devoid of much variety, and asked to rephrase sentence starters using appropriate ones from a given list. 
Recommendations based on this study can also be made for researchers. One of the limitations of this study was that it only considered the frequency of sentence openers in the texts analyzed. Future research could consider investigating the quality of sentence openers in student papers. This would help identify challenges students face with particular types of sentence openers. It would also be a good idea to investigate types of sentence openers in different genres, and authors' reasons for opting for particular types in particular sections of papers. To this end, research articles might be compared to academic texts of general interest. Also, an experimental study could be designed to assess the impact of instructional design on students' use of sentence openers together with other ways of achieving variety in their prose. Longitudinal studies for such purposes may be particularly useful.

\section{References}

Agnew, S., \& Harrison, N. (2017). The role of gender, cognitive attributes and personality on willingness to take risks. Business and Economic Research, 7(1), 1-16. https://doi.org/10.5296/ber.v7i1.10371

Alley, M. (1996). The craft of scientific writing. New York: Springer. https://doi.org/10.1007/978-14757-2482-0

American Psychological Association. (2009). Publication manual of the American Psychological Association. Washington, D.C.: American Psychological Association.

Deveci, T. (in press). Sentence length in education research articles: A comparison between Anglophone and Turkish authors. The Linguistics Journal, 14(1).

Deveci, T., \& Nunn, R. (2018). The use of relative clauses in humanities and social sciences research articles: A case study. Linguistics and Literature Studies, 6(1), 17-26. https://doi.org/10.13189/1ls.2018.060103

Gopen, G. D., \& Swan, J. A. (1990). The science of scientific writing. American Scientist, 78(6). 550558.

Hashimoto, I. (1993). Sentence variety: Where theory and practice meet and lose. Composition Studies: Freshman English News, 21, 66-77.

Hinkel, E. (2004). Teaching academic ESL writing: Practical techniques in vocabulary and grammar. Mahwah, NJ: Lawrance Erlbaum Associates. https://doi.org/10.4324/9781410609427

Hogsette, D. S. (2009). Writing that makes sense: Critical thinking in college composition. Eugene, OR: Resource Publications.

Imam, H. (2013). Straight to yes! Asking with confidence and getting what you want. West Sussex: Capstone.

Ioannidou, M. K. (1997). Testing and life-long learning: Open-book and closed-book examination in a university course. Studies in Educational Evaluation, 23(2), 131-139.

Jia, P. (2006). Simple approaches to writing short essays (for students of English as a second language). Lincoln, NE: iUniverse.

Killgallon, D. (1987). Sentence composing: The complete course. Portsmouth, NH: Boynton/Cook Publishers.

Kim, Y. S., \& Snow, C. E. (2009). Text modification: Enhancing English language learners' reading comprehension. In E. H. Hiebert, \& M. Sailor (Eds). Finding the right text: What works for 
beginning and struggling learners' reading comprehension (129-46). New York, NY: The Guildford Press.

Krashen, S. (1984). Writing: Research, theory and application. Oxford: Pergamon Institute of English. https://doi.org/10.1017/s0272263100006197

Liu, H. (2013). Effects of foreign language anxiety and perceived competence on learning strategy use. International Journal of English Linguistics, 3(3), 76-87.

Mamishev, A., \& Williams, S. (2010). Technical writing for teams: The STREAM tools handsbook. New Jersey: John Wiley \& Sons, Inc. https://doi.org/10.1002/9780470602706

Myhill, D. (2008). Toward a linguistic model of sentence development in writing. Language and Education, 2(5), 271-288. https://doi.org/10.2167/le775.0

Pajares, F., \& Johnson, M. J. (1994). Confidence and competence in writing: The role of self-efficacy, outcome expectancy, and apprehension. Research in the Teaching of English, 28(3), 313-331.

Paraskevas, C. (2006). Apprenticeship. The English Journal, 95(5), 65-70. https://doi.org/10.2307/30046591

Pennington, M. (2009). Essential study skills: Self-guided personal assessment, study skill tips, and reflection workbook. El Dorada Hills, CA: Pennington Publishing.

Raimes, A., \& Miller-Cochran, S. K. (2018). Keys for writers. Boston, MA: CENGAGE Learning.

Riley, W. K. (1964). Sentence openers in freshman writing. College English, 26(3), 228-230. https://doi.org/10.2307/373597

Ringler, M. C. (2015). Academic language literacy: Developing instructional leadership skills for principals and teachers. Maryland: Rowman \& Littlefield.

Sayidina, A. M. (2010). Transfer of L1 cohesive devices and transition words into L2 academic texts: The case of Arab students. RELC Journal, 41(3), 253-266. https://doi.org/10.1177/0033688210380569

Smith, R. N. (1982). Computerized aids to writing. In W. Frawley (Ed.). Linguistics and literacy (pp. 189-208). New York and London: Plenum Press. https://doi.org/10.1007/978-1-4615-9302-7_9

Starkey, D. (2015). Academic writing now: A brief guide for busy students. Ontario: Broadview Press.

Struc, N., \& Wood, N. (2011). A corpus-based investigation of syntactic complexity, fluency, sentence variety, and sentence development in L2 genre writing. Reitaku University Journal, 93, 45-79.

Sultan, S. (2012). Students' perceived competence affecting level of anxiety in learning English as a foreign language. Pakistan Journal of Psychological Research, 27(2), 225-239.

Swales, J. M., Ahmad, U. K., Chang, Y. Y., Chavez, D., Dressen, D. F., \& Seymour, R. (1988). Consider this: The role of imperatives in scholarly writing. Applied Linguistics, 19(1), 97-121. https://doi.org/10.1093/applin/19.1.97

Theophilides, C., \& Koutselini, M. (2000). Study behavior in the closed-book and the open-book examination: A comparative analysis. Educational Research and Evaluation, 6(4), 379-393.

Walter, J. (2017). Building writing skills: The hands-on way. Boston: Cengage Learning.

Wolfe, D. M. (1950). Variety in sentence structure: A device. College English, 11(7), 394-397. https://doi.org/10.2307/586025 


\section{Appendix A. List of seminar texts}

Craig, R., \& N. Ayish, N (2016). Interpersonal communication. Unpublished manuscript, Communication Department, the Petroleum Institute, Abu Dhabi, UAE.

Deveci, T. \& Nunn, R. (2016). Intrapersonal communication and its place in engineering education. Unpublished manuscript, Communication Department, the Petroleum Institute, Abu Dhabi, UAE.

Premier (2016). A primer on communication studies, chapter 5. Creative Commons. Retrieved from http://2012books.lardbucket.org/books/a-primer-on-communication-studies/index.html on 10 January 2016.

Wyatt, M., \& D. Dalton, D. (2016). Barriers to intercultural communication and how to overcome them through developing intercultural communicative competence. Unpublished manuscript, Communication Department, the Petroleum Institute, Abu Dhabi, UAE

\section{Akademik metinlerde cümle aç1lışları: Seminer metinleri ve öğrencilerin yansıtıcı yazıları arasında bir karşılaştırma}

\section{$\ddot{O} \mathbf{z}$}

Argüman ortaya koyma ve araştırma sonuçlarının rapor edilmesinde kullanılan dilin doğru ve etkili kullanılması oldukça önemlidir. Ancak bu şekilde okuyucularla etkili bir iletişim sağlanabilir. Yazarlar bu amaçla dile ilişkin gramer, kelime kullanımı gibi farklı biçimsel özelliklerden faydalanırlar. Bu özellikler üzerine oldukça fazla sayıda araştırma yapılmış bulunmaktadır. Ancak cümle açılışları üzerine yeterli çalışma yapılmadığı görülmektedir. Cümle açılışlarının stratejik kullanımı yazarların kendilerine has bir stil geliştirmelerine yardımcı olacaktır. Ayrıca yazıları daha akıcı hale gelecektir. Bu şekilde yazarlar bilimsel bilgileri okuyucularına daha etkin şekilde iletebileceklerdir. Bu nedenlerden dolayı üniversite öğrencilerinin akademik yazmanın önemli bir unsuru olan cümle açılışlarına ilişkin olarak farkındalık kazanmaları gerekmektedir. Bunu elde etmek için ise öğrencilerin derslerinde okudukları metinlerde sıklıkla kullanılan cümle açılışlarının belirlenmesi faydalı olacaktır. Öğrencilerin kendilerinin kullanma eğiliminde oldukları cümle açılışlarının ve bu konuda yetkinliklerine ilişkin görüşlerinin de belirlenmesi faydalı olacaktır. Bu araştırmada Abu Dhabi'deki bir üniversitede birinci sınıf iletişim dersinde okutulan 10,949 kelimelik bir korpus incelenmiştir. Ayrıca öğrencilerin kendileri tarafindan yazılmış olan 42,070 kelimelik ikinci bir korpus incelenmiştir. Öğrencilerin yetkinlik düzeylerine ilişkin görüşleri ise bir anket aracılığıyla toplanmıştır. Sonuçlar her iki korpusta da en sık kullanılan cümle açılışlarının özne-fiil ve geçiş belirteçleri olduğunu göstermiştir. Geçiş belirteçlerinin öğrenciler tarafından çok daha sık kullanıldığı belirlenmiştir. Ayrıca yazıların daha ilgiyle okunmasına katkı sağlayan cümle geçişlerine ilişkin öğrenci farkındalık düzeyinin düşük olduğu belirlenmiştir. Öğrenciler ayrıca farklı türden cümle açılışları kullanımına ilişsin yetkinliklerinin düşük seviyede olduğunu belirtmişlerdir. Sonuçlar tartışılmakta ve öğrencilerin daha etkili akademik metinler yazmalarına yardımcı olacak önerilerde bulunulmaktadır.

Anahtar sözcükler: Cümle açılışları; cümle çeşitliliği; academik yazma becerileri 


\section{AUTHOR BIODATA}

Tanju Deveci is an Associate Professor of Lifelong Learning. He is currently teaching English at Khalifa University of Science and Technology in Abu Dhabi. He teaches communication skills to engineering students with a heavy focus on writing. His research interests include academic writing, pragmatic competence, learning styles, students' learning orientations, lifelong and limitless learning. 